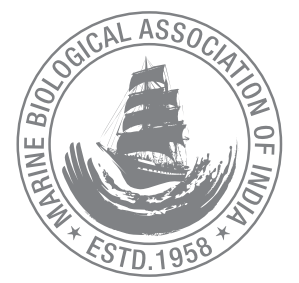

\title{
Similarities between Indian oil sardine Sardinella longiceps Valenciennes, 1847 and global sardine fisheries and its management
}

\author{
V. Kripa*, K. S. Mohamed, Shelton Padua, R. Jeyabaskaran and D. Prema \\ ICAR-Central Marine Fisheries Research Institute, PO Box 1603, Kochi -682 018, Kerala, India. \\ *Correspondence e-mail: vasantkripa@gmail.com
}

Received: 01 Sep 2018 Accepted: 15 June 2019 Published: 30 June 2019

Original Article

\begin{abstract}
Small pelagic fishes categorized as Herrings, Anchovies and Sardine (HAS) in FAO fisheries statistics have contributed to world fish landings considerably; ranging from $42.7 \%$ of the world marine fish production in 1964 and to a low of $19 \%$ in 2014. An analysis of commercially important sardine fishery across the globe during last six decades from 1956 to 2015 was attempted which indicated that there is considerable variation in the magnitude of production between countries and species. Comparison of variation in fishery of four species of Sardinops, one species of Sardina and seven species of Sardinella clearly indicated that the landing of oil sardine (Sardinella longiceps) from the Indian sub-continent is considerably higher than that of most major sardine species across the globe. During the last decade (2006 to 2015), the average landing of oil sardine was $0.50 \times 10^{6}$ tonnes and was ranked second among sardine group, first being Sardina pilchardus ( $1.11 \times 10^{6}$ tonnes). In the present manuscript, the spatial pattern of the contribution of each country to world sardine production (long term and decadal average) and its deviation have been plotted on a GIS platform. The extensive investigations spanning over 60 years on the large scale fluctuations on sardine -anchovy fisheries in the Pacific and Atlantic has identified impacts of regime shifts and other environmental variations, eco-biological changes, overfishing or a combination of all these on the decline and revival of sardine biomasses. Similar
\end{abstract}

detailed investigations covering larval ecology and sardine habitat variations are yet to be attempted for the tropical Asian sardine resources. Considering the global significance of oil sardine population along the coastal upwelling zone of south-eastern Arabian Sea, it is suggested that collaborative integrated research on small pelagics of Southeast Asia be planned and developed to increase the efficiency of predictive modelling. The various management measures adopted globally for sardines is also presented which would support decision making for planners to support the livelihood of fishers when sardine stocks decline drastically.

Keywords: Indian oil sardine, global sardine fisheries, catch fluctuations, GIS maps

\section{Introduction}

Sardines are fishes belonging to the family Clupeidae which mostly inhabit the near-shore pelagic zone. They form a part of the group of fishes called "small pelagics" in comparison and contrast to the large pelagics like tunas, billfishes and swordfishes. They have wide distribution in the Atlantic, Pacific 
and Indian Ocean, where they form an integral part of the marine food chain. There are different species of sardines and they are sometimes called "pilchards".

World marine fish landings increased from $24.1 \times 10^{6}$ tonnes in 1956 to $87.5 \times 10^{6}$ tonnes in 1996 and thereafter the average catch per annum was $82.5 \pm 2.5 \times 10^{6}$ tonnes (Fig. 1). Small pelagic fishes categorized as Herrings, Anchovies and Sardine (HAS) according to FAO fisheries statistics have contributed to world fish landings considerably, as high as $42.7 \%$ of the world marine fish production in 1964 and to a low of 19\% in 2014. These fishes have shown large fluctuations in abundance related either to environmental variations or due to overfishing or a combination of both. Fishery collapses are characterized by a reduction in catch of less than $10 \%$ of the maximum and a long recovery time (Worm et al., 2009; Petitgas et al., 2010; Mohamed and Veena, 2016).

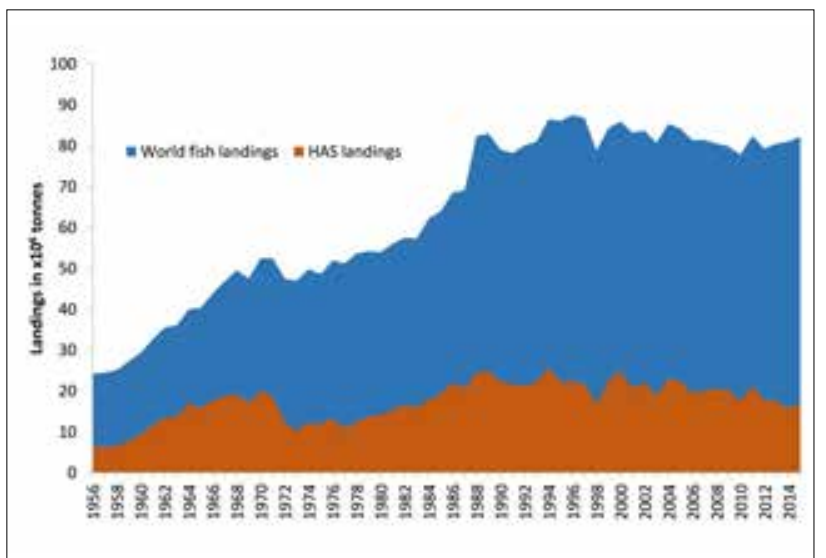

Fig. 1. World marine fish landings and total landing of the HerringAnchovy-Sardine (HAS) group. Source: FAO

One of the first reports to identify a remote link or a synchronization in the fluctuations of the small pelagics of the Pacific Ocean (Japan, California and Humboldt) is Kawasaki (1983) and this developed as the "Regime Shift" concept. Many authors have linked several aspects of ocean-atmospheric processes, eco-biological variations, larval ecology and recruitment success to small pelagic fishery fluctuations (LluchBelda et al., 1989, 1992; Schwartzlose et al., 1999, Sumaila et al., 2011; Lindegren et al., 2013; Zwolinski and Demer, 2012; Brosset et al., 2017).

Associated with spawning success and larval survival, the "optimal environmental window" a concept suggested by Cury and Roy (1989) when all biotic and abiotic environmental conditions permit successful recruitment has also been identified as a possible reason for sardine decline in several parts of the world. Similarly the "school trap" situation when multi-species shoals of similar sized small pelagics occur wherein some groups may be at disadvantage but prefer to remain in the group has been suggested as a reason for low recruitment success (Bakun and Cury, 1999). A metaanalysis of 38 fish stocks of 13 species in the NE Atlantic to quantify the independent effects of exploitation pattern and exploitation rate on stock status have shown that when the fishing mortality of immature fish exceeds half that of mature fish, stock status falls below precautionary limits supporting the spawn-at-least-once" principle (Vasilakopoulos et al., 2011).

Peck et al. (2013) reviewed the work done on the ecophysiology and climate driven changes on small pelagics including European sardine (Sardina pilchardus) and Japanese sardine (Sardinops melanostictus). This extensive review has identified the research gaps which have to be addressed to develop good predictive models. In a recent study conducted by updating the time series data of small pelagics to check the whether the regime change problem exists, Izquierdo-Peña et al. (2019) observed that the multi-decadal synchrony remains clear for the Kuroshio and Humboldt systems and but there is no single worldwide model of variability tele-connecting all small pelagics.

The magnitude of the fishery of Japanese sardine $S$. melanostictus and the Californian sardine during the $20^{\text {th }}$ century was so high that their inter-annual variations not only affected the fishermen and the State's economy, but also had severe ecological disturbances (Petitgas et al., 2010; Pikitch et al., 2014).

The Indian oil sardine, Sardinella longiceps, has a distribution limited to tropical waters of northern and western Indian Ocean (Gulf of Aden, Gulf of Oman, but apparently not Red Sea or the Persian Gulf, and eastward to India, including the Andaman Islands). During the period 1950 to 2015, India has been the major contributor of oil sardine catch. Among the Indian maritime states, the southern state of Kerala is one of the most productive upwelling zones (Banse, 1959) along the south-eastern Arabian Sea and has always been the major producer of oil sardine (Hornell, 1937, Nair and Chidambaram 1951; Pillai et al., 2003). With average annual landing of $2.2 \times 10^{5}$ tonnes during 2001 to 2010 , the Kerala State's landings exceeded the catch from other nations like Oman, Yemen, Iran and Pakistan (FAO, 2016).

The fishery of oil sardine in India has shown fluctuations during the 1900s and revived back without long term collapses as observed in other sardine populations. In this decade the sardine fishery along the Kerala coast declined since 2012 severely affecting the income of fishermen (Salim et al., 2017). The reasons for the decline has been attributed to both overfishing and habitat variations especially changes 
in precipitation, food availability and increased temperature (Kripa et al., 2018). Earlier studies have linked environmental variations such as rainfall (Raja, 1969; Xu and Boyce, 2009), upwelling (Longhurst and Wooster, 1990) and sunspot activities (Jayaprakash, 2002) for sardine decline.

In this manuscript, global catches of commercially important sardine species of the genera Sardinops, Sardina and Sardinella are compared with Indian oil sardine fisheries and its decadal variations are presented. The analysis is an attempt to bring out the significance of oil sardine fishery of Indian Ocean as a globally important small pelagic fishery and the habitat along southeastern Arabian Sea as an important coastal upwelling zone. The analysis is also an attempt to bring out the need for integrated research programs focusing on warm-cold phase-changes and its impacts on oil sardine fishery and its influences on life cycle processes of small pelagic of the Asian tropical region.

\section{Data and Methodology}

For decadal analysis of the catch data of different commercially important sardine species, the FAO global capture fisheries database (http://www.fao.org/fishery/statistics/en) was used. For each species apart from the global total, the country wise contribution was also used for the analysis. For Indian oil sardine catch estimates of Indian states, the data maintained at the National Marine Fisheries Data Centre (NMFDC) of ICAR-Central Marine Fisheries Research Institute, Kochi was used. The averages for six decades were estimated for countrywise for each species. For better visualization of the spatial pattern of the contribution of each countries to world sardine production (long term and decadal average) and its deviation were plotted on Geographic Information System (ArcGIS 10.0). Historical (1845 to 1950) records of oil sardine catches were taken from Nair and Chidambaram (1951).

\section{Overview of global sardine fishery}

Analysis of the annual landing of HAS group for six decades from 1956 to 2015 shows that the average annual catch increased from about 11.4 million metric tonnes (mmt) in $1956-65$ to 22.7 $\mathrm{mmt}$ during 1986-95. The landings fluctuated in the following decades. Contribution by this group to the total global marine fish production during different decades was highest (33.7\%) during 1956-65 and decreased thereafter reaching 23\% during 2005-15 (Table 1).

With around 44 species and several unidentified species, the HAS group plays a significant role in coastal economy and in the regional food chains. Mullon et al. (2005) have analysed 1519 main series of the FAO world fisheries catch database for a period of 50 years and this has revealed that of the 161 stocks in the HAS group, $38(28 \%)$ have shown collapses.

One of the main species of this group is the Peruvian anchovy, Engraulis ringens, which contributed to one fourth $\left(13.05 \times 10^{6}\right.$ tonnes) of the world marine fish production in 1971, but later on the fishery declined. The fishery has shown wide inter-annual fluctuations and is well known for the influence of $E /$ Niño and La Nina on stock abundance and recruitment. In spite of these fluctuations, the Peruvian anchovy has remained the major contributor of this group since 1956 (Fig.2). One interesting character about this species is the ability to recover following drastic declines.

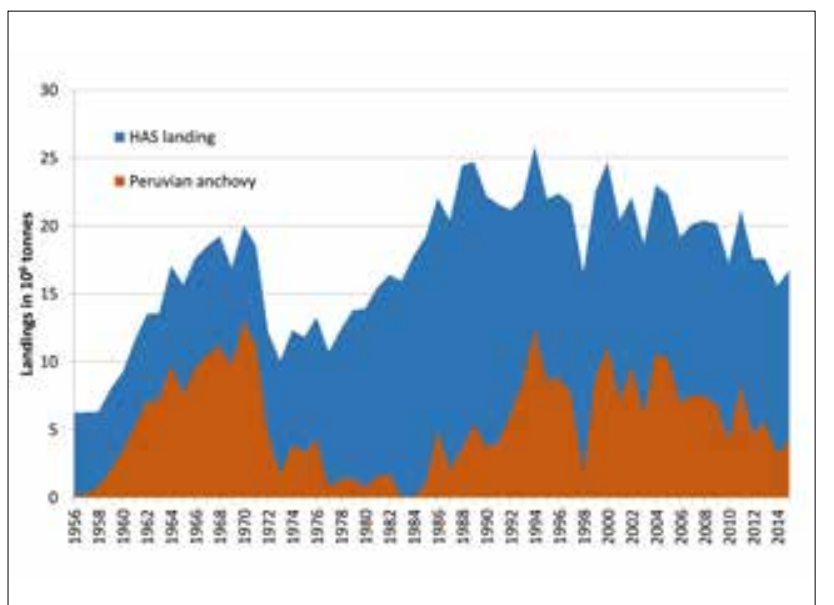

Fig. 2. Annual landing of HAS group and Peruvian anchovy during the period 1956 to 2015. Source: FAO

\begin{tabular}{|c|c|c|c|c|c|c|}
\hline Decade & $\begin{array}{l}\text { Average World fish } \\
\text { landings million tonnes }\end{array}$ & HAS landings & $\begin{array}{l}\% \text { of HAS to world } \\
\text { landings }\end{array}$ & Engraulis ringens & $\begin{array}{l}\% \text { contribution by } E \text {. ringens } \\
\text { to world landings }\end{array}$ & $\begin{array}{l}\% \text { contribution by } \\
\text { E. ringens to HAS }\end{array}$ \\
\hline $1956-65$ & 32.6 & 11.4 & 33.7 & 4.86 & 13.3 & 35.9 \\
\hline $1966-75$ & 48.6 & 15.7 & 32.4 & 7.92 & 16.2 & 47.0 \\
\hline $1976-85$ & 56.2 & 14.9 & 26.4 & 1.33 & 2.4 & 9.5 \\
\hline $1986-95$ & 79.4 & 22.7 & 28.6 & 5.97 & 7.4 & 26.0 \\
\hline 1996-05 & 84.1 & 21.4 & 25.4 & 8.23 & 9.7 & 37.5 \\
\hline 2006-15 & 80.6 & 18.6 & 23.0 & 5.93 & 7.3 & 31.3 \\
\hline
\end{tabular}




\section{Fluctuations in the fishery of major species of sardines}

The HAS group has sardines / pilchards belonging to five genera such as the Sardinella (seven species), Sardinops (five species), Sardina (one species), Dussumeria (two species) and Ambygaster (one species) which form commercially important fisheries in several locations(Fig. 3). In this section, we are presenting information on species of the first three genera.

During the period 1956 to 2015, fishery fluctuations were observed in several parts of the world. An analysis of the variations in fishery indicated that the countries which were the major producers of sardines during the recent decade

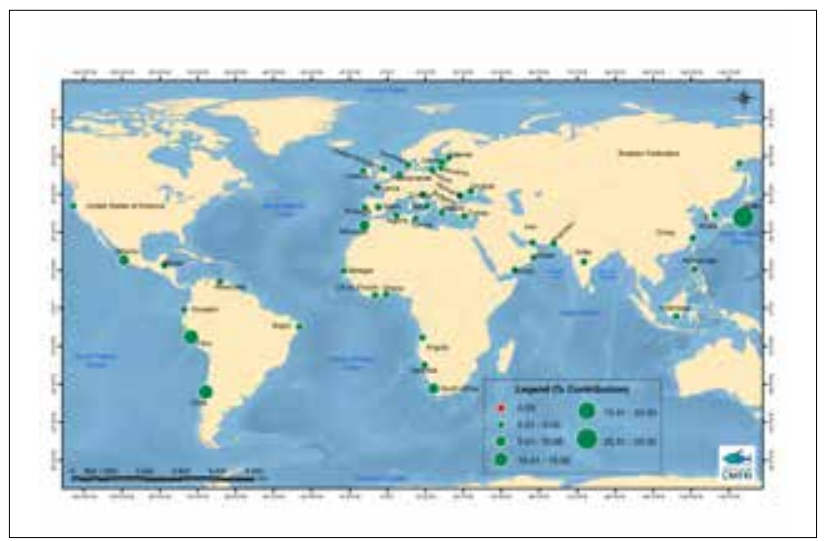

Fig. 3. Country-wise contribution to world sardine production (19562015 Average).Data Source: FAO
(2006-2015) were different from those which dominated during the earlier decades (Fig. 3 and 4). In several regions there were drastic decline when compared with the long term average (Fig. 5). The fluctuations from the Indian sub-continent was not as severe compared to that of other locations (Fig. 4 and 5).

Six sardine species have contributed significantly to HAS group during the period 1956 to 2015 (Fig. 6) [Japanese pilchard (S. melanostictus), South American sardine (Sardinops sagax), African sardine, (Sardinops ocellatus), European pilchard (Sardina pilchardus), Californian sardine (Sardinops caeruleus) and Indian oil sardine (Sardinella longiceps)]. These have formed one of the top ten species in the HAS group at different periods during the last six decades. The landings of these six species were so high that these have together contributed to a highest of $13.1 \%$ of global marine fish landing during the decade 1976-1985 and 49\% of the HAS landing (Table 2a). Subsequently the impacts of overfishing and environmental variations affected these stocks and the decline in the landing of these species is reflected in their contribution to the global marine fish landing, bringing it to a low of $3.1 \%$ in the last decade and $13.5 \%$ of HAS landing (Table $2 \mathrm{~b}$ ).

\section{Species of the genus Sardinops}

Four species of the genus Sardinops have contributed significantly to HAS group; S. sagax, S. melanostictus, S. caeruleus and $S$. ocellatus and a brief description of these are given below.

Table 2a. Percentage contribution by major species of sardines to world landings during different decades from 1956 -2015

\begin{tabular}{|c|c|c|c|c|c|c|c|}
\hline Decade & $\begin{array}{l}\text { Sardinops } \\
\text { melanostictus }\end{array}$ & Sardina pilchardus & $\begin{array}{l}\text { Sardinops } \\
\text { caeruleus }\end{array}$ & $\begin{array}{l}\text { Sardinops } \\
\text { sagax }\end{array}$ & Sardinella longiceps & Sardinops ocellatus & $\begin{array}{l}\text { Total to World } \\
\text { landings }\end{array}$ \\
\hline $1956-65$ & 0.4 & 1.5 & 0.1 & 0.0 & 0.5 & 2.1 & 4.6 \\
\hline $1966-75$ & 0.3 & 1.2 & 0.1 & 0.2 & 0.4 & 1.7 & 3.9 \\
\hline $1976-85$ & 4.7 & 1.3 & 0.5 & 5.8 & 0.5 & 0.3 & 13.1 \\
\hline $1986-95$ & 4.0 & 1.5 & 0.5 & 4.7 & 0.3 & 0.2 & 11.2 \\
\hline 1996-05 & 0.4 & 1.2 & 0.6 & 0.5 & 0.4 & 0.3 & 3.4 \\
\hline 2006-15 & 0.4 & 1.4 & 0.6 & 0.0 & 0.6 & 0.2 & 3.1 \\
\hline
\end{tabular}

Table 2b. Percentage contribution by major species of sardines to total landings of HAS group during different decades from 1956 -2015

\begin{tabular}{|c|c|c|c|c|c|c|c|}
\hline Decade & $\begin{array}{l}\text { Sardinops } \\
\text { melanostictus }\end{array}$ & Sardina pilchardus & $\begin{array}{l}\text { Sardinops } \\
\text { caeruleus }\end{array}$ & Sardinops sagax & Sardinella longiceps & Sardinops ocellatus & Total \\
\hline $1956-65$ & 1.3 & 4.6 & 0.5 & 0.0 & 1.5 & 6.22 & 14.1 \\
\hline 1966-75 & 1.2 & 4.0 & 0.4 & 0.6 & 1.3 & 5.27 & 12.8 \\
\hline $1976-85$ & 17.5 & 5.0 & 1.8 & 21.3 & 2.1 & 1.05 & 48.8 \\
\hline $1986-95$ & 13.8 & 5.3 & 1.7 & 16.2 & 1.2 & 0.59 & 38.7 \\
\hline 1996-05 & 1.4 & 4.8 & 2.5 & 2.0 & 1.6 & 1.06 & 13.4 \\
\hline $2006-15$ & 1.6 & 6.0 & 2.4 & 0.0 & 2.7 & 0.74 & 13.5 \\
\hline
\end{tabular}




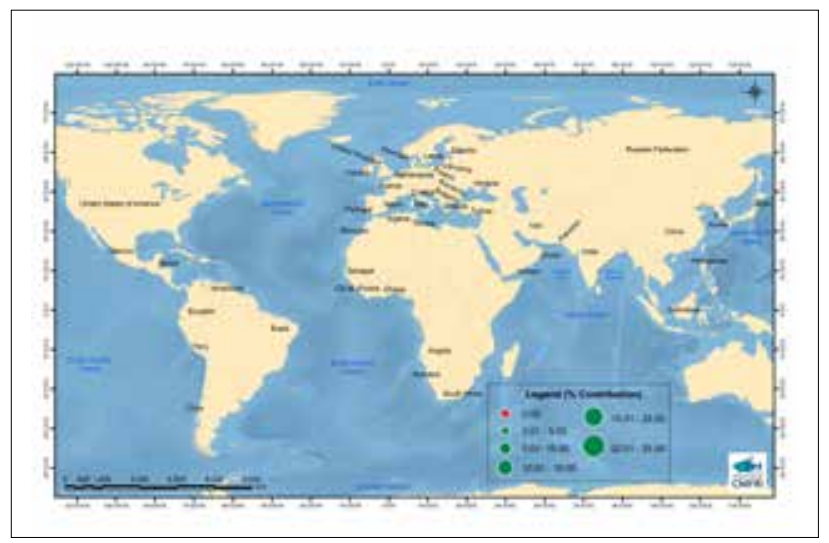

Fig. 4. Country-wise contribution to world sardine production (20062015 Average). Data Source: FAO

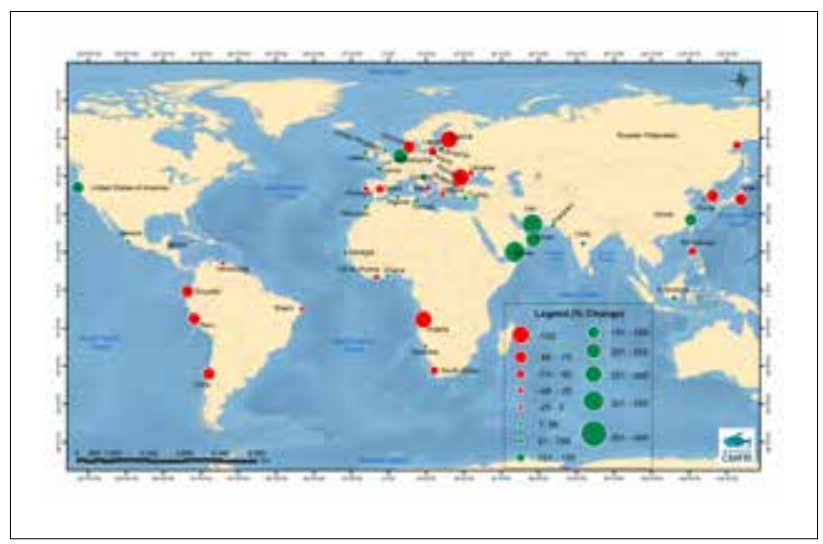

Fig.5. Country-wise change in sardine production (deviation in decadal production (2006-2015) compared to long term average (1956-2015). Data source: FAO

\section{South American sardine Sardinops sagax}

S. sagax or the American pilchard forms a good fishery in Peru, Chile, Ecuador Cuba, Asia and Europe. The decadal average landings of this species was very low till 1975 (Table 3) but increased to 3.33 million tonnes during 1976 to 1985 reaching 3.64 million tonnes in 1985 to 1995 contributing 4.7 to $5.8 \%$ to the global marine fish landings. The same trend was reflected in the annual landings also (Fig. 6). Thereafter, the landings decreased considerably and became much lower than that of oil sardine from India. The major share of $S$. sagax is from Peru and Chile (Fig. 7). The inter-annual variability in recruitment of S. sagax has been attributed to a combination of factors such as changes in the environment, intra and interspecific relationships and even overfishing (Mata et al., 1995). More recently GalindoCortes et al. (2010) have indicated that recruitment of Pacific sardine has a density-dependent mortality term for eggs and juvenile stages, related to the total spawning stock biomass

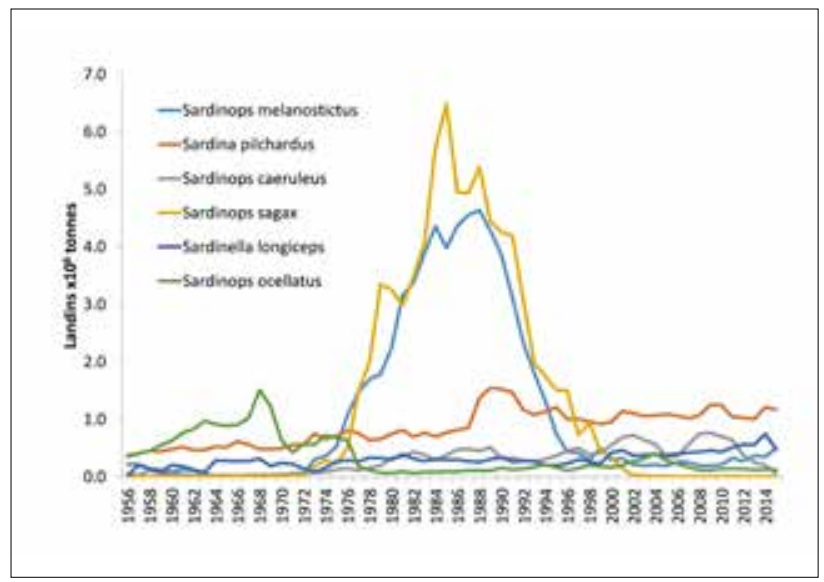

Fig. 6. Annual trend in landings of major sardines during the period 1956 to 2015

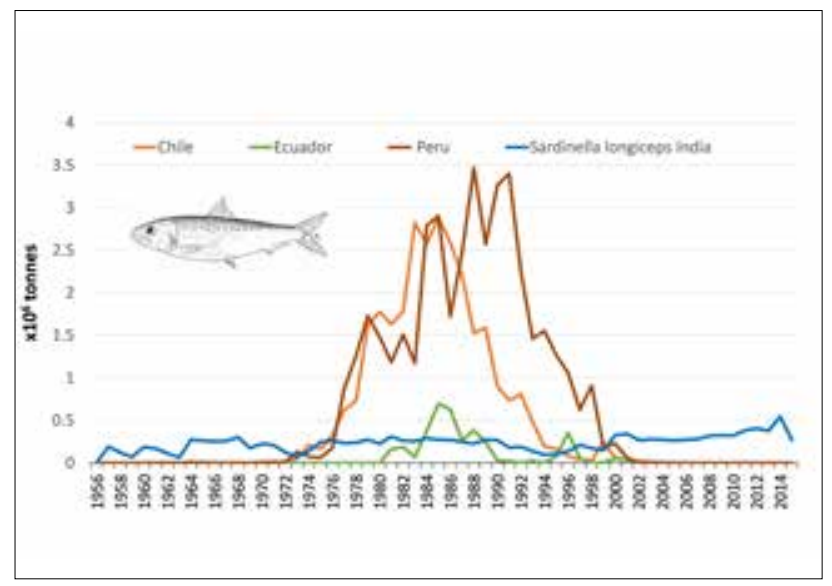

Fig.7. Major contributing countries of American sardine S. sagax and oil sardine-India-comparison. Source: FAO

Table 3. Average decadal landing ( $\times 10^{6}$ tonnes) of major sardine

\begin{tabular}{|c|c|c|c|c|c|c|}
\hline & Sardinops melanostictus & Sardina pilchardus & Sardinops caeruleus & Sardinops sagax & Sardinella longiceps & Sardinops ocellatus \\
\hline $1956-65$ & 0.10 & 0.47 & 0.04 & 0.00 & 0.17 & 0.69 \\
\hline $1966-75$ & 0.14 & 0.58 & 0.05 & 0.08 & 0.21 & 0.82 \\
\hline $1976-85$ & 2.70 & 0.73 & 0.27 & 3.33 & 0.31 & 0.14 \\
\hline $1986-95$ & 3.10 & 1.21 & 0.38 & 3.64 & 0.26 & 0.13 \\
\hline 1996-05 & 0.30 & 1.03 & 0.52 & 0.41 & 0.34 & 0.22 \\
\hline 2006-15 & 0.29 & 1.11 & 0.46 & 0.00 & 0.50 & 0.14 \\
\hline
\end{tabular}


and cohort size and that the impact of warm episodes was not uniform in all regions. The unfavourable environmental conditions together with high exploitation rates of large spawners have reduced the stock of $S$. sagax in the Northeast Pacific and this situation if persisting can delay the recovery of the stock (Zwolinski and Demer, 2012).

\section{Japanese pilchard Sardinops melanostictus}

The Japanese commercial fishery for Japanese pilchard/ sardine S. melanostictus dates back to 1487 . Originally, sardines were taken by beach seines, fish traps, and gillnets for human consumption (Sonu, 2001). The annual catch of this species was at times the greatest among all fish landed in the world. The Japanese sardine has been found to exhibit repeating long-term fluctuation in stock abundance with high and low levels since 17 th century. In the 20th century, a peak in catch occurred in the 1930s (highest 1.8 million tonnes in 1935), followed by a rapid decline in the 1940's (lowest 150,000 tonnes).

Japanese pilchard is one of the major sardine resources of the world and the highest landing during the period 1956 to 2015 was $44.9 \times 10^{5}$ tonnes during 1988 from Japan (Fig. 8). This sardine is also fished from China, Korea and Russian waters. However, the contribution from these regions is very low compared to Japanese waters. The landings of Japanese sardine also showed the same trend as that of S. sagax, low during the first two centuries, increasing during 1976-95 and thereafter decreasing considerably. The individual-based life cycle model and simulations applied on $S$. melanostichus revealed that the sardine stock decline in the 1990s was influenced by environmental factors, interspecific-relationships and fishing and it could not have been prevented by catch regulations. A reduction

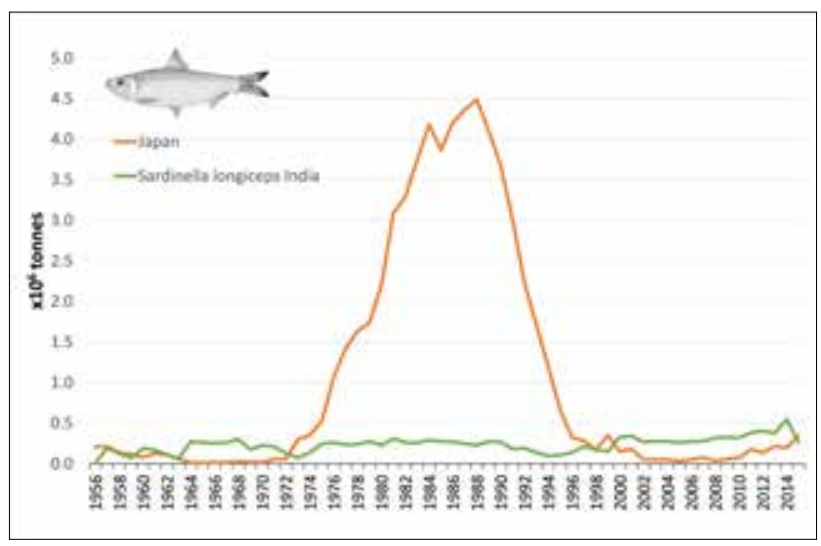

Fig. 8. Comparison of Japanese Pilchard, S. melanostictus and Indian oil sardine landings in million tonnes. Source: FAO of the fishing mortality could have helped to mitigate the situation and helped the stock to recover (Suda et al., 2005). The landings of Indian oil sardine from Indian water were higher than this species during the period 1956 to 1975 and from 2000 onwards.

\section{African sardine Sardinops ocellatus}

African sardine forms a commercial fishery in South Africa, Angola and Namibia (Fig. 9). This species was the dominant sardine during 1956 to 1975 and formed nearly 1.7 to $2.1 \%$ of the global marine landings. However, the landing declined

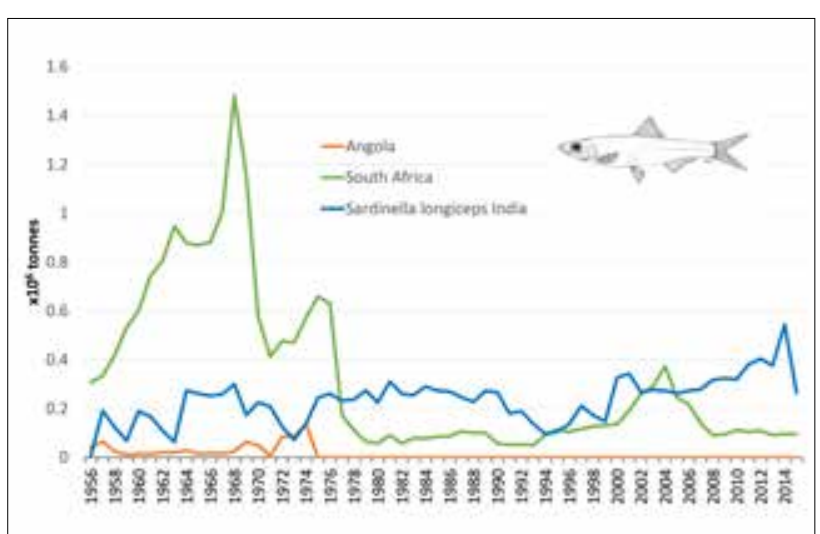

Fig. 9. Comparison of African sardine, S. ocellatus and Indian Oil sardine landings in million tonnes. Source: FAO

thereafter and were much lower than that of Indian oil sardine except during the year 2000 (Fig. 9).

\section{Californian sardine Sardinops caeruleus}

Californian sardine fishery along the Mexican and US coasts have shown wide fluctuations. Unlike the African sardine, the Californian sardine fishery was not intense during the decade, 1956-65. From 1968 the Mexican fishery began to improve and showed several ups and downs. The Indian oil sardine fishery was considerably bigger than the Californian sardine fishery till about 1979 (Fig. 10). Thereafter, the magnitude of oil sardine fishery was lower than that of the fishery along Mexico. However, the fluctuations were similar and during the present decade, the fishery declined just as the oil sardine declined along Indian coast (Fig. 10).

\section{Species of the genus Sardina}

The most important species of the genus Sardina is the European pilchard and a brief description on the contribution by this species to global sardine fishery is given below. 


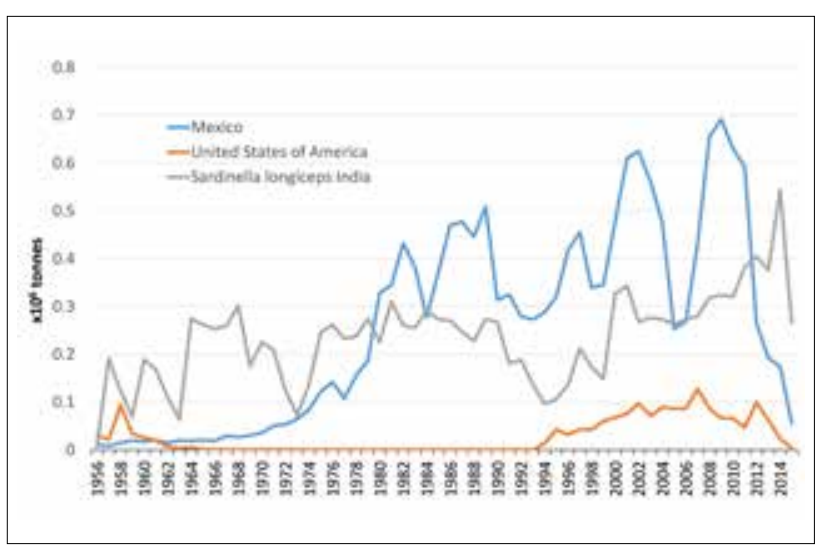

Fig. 10. Comparison of Californian sardine (S. caeruleus) and Indian oil sardine landings in million tonnes. Source: FAO

\section{European pilchard Sardina pilchardus}

European pilchard has a wider distribution and forms a fishery in several countries of Africa, Europe, America and Asia. However, the major fishery is along European and African coasts (Fig. 11). Till about 1996, the production from European countries was higher than that from African coasts. However, from 1996, the landings from Europe declined and their contribution was less than $40 \%$ of the total S. pilchardus landings.

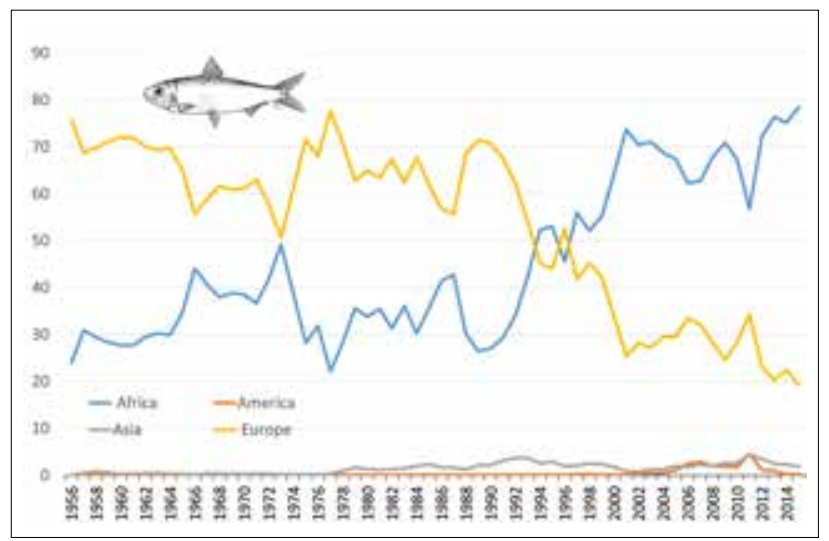

Fig. 11. Region wise contribution of European pilchard, S. pilchardus from 1956 to 2015. Source: FAO

The most prominent sardine fishing area in Europe is Spain while in Africa, the highest landings are from Morocco. Till about 1988, the quantity of sardines fished from Morocco and Spain were almost same, but thereafter, the fishery declined in Spain while in Morocco it increased. The quantity of Indian oil sardine caught along Indian coast was also at par with the European pilchard landings at Morocco and Spain till 1988, but Indian oil sardine landings since then was higher than that of Spain, but less than the landings at Morocco (Fig. 12).

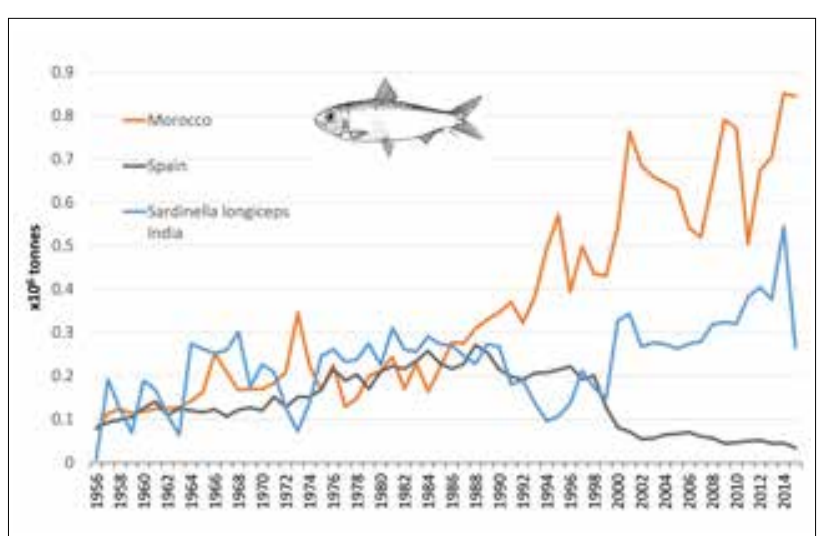

Fig.12. Landings of major producing countries of $S$. pilchardus in comparison with Indian oil sardine landings in million tonnes. Source: FAO

\section{Species of the genus Sardinella}

Seven species of the genus Sardinella (Sardinella longiceps, Sardinella aurita, Sardinella brasiliensis, Sardinella maderensis, Sardinella lemuru, Sardinella gibbosa and Sardinella zunasi) are reported in the FAO database. The total landings by all these together have shown an increasing trend from $3.12 \times 10^{5}$ tonnes in 1956-65 to $13.49 \times 10^{5}$ tonnes in 2006-15, though there were wide fluctuations within the group (Fig. 13). The contribution by this group to the HAS also increased from 3.0 to $7.3 \times 10^{5}$ tonnes during this period (Table 4).

\section{Indian oil sardine Sardinella longiceps}

Indian oil sardine is a major species and commercial fishery has been reported from six countries viz. India, Iran, Oman, Pakistan, United Arab Emirates and Yemen. The average annual landing was $1.55 \times 10^{5}$ tonnes in 1956-65, which increased to $4.95 \times 10^{5}$ tonnes in 2006-15 (Fig. 14). However, there was a decline during the period 1986-2005. The contribution by this species to the Sardinella group was highest (46.3\%) during 1956-65 and declined in the following decades.

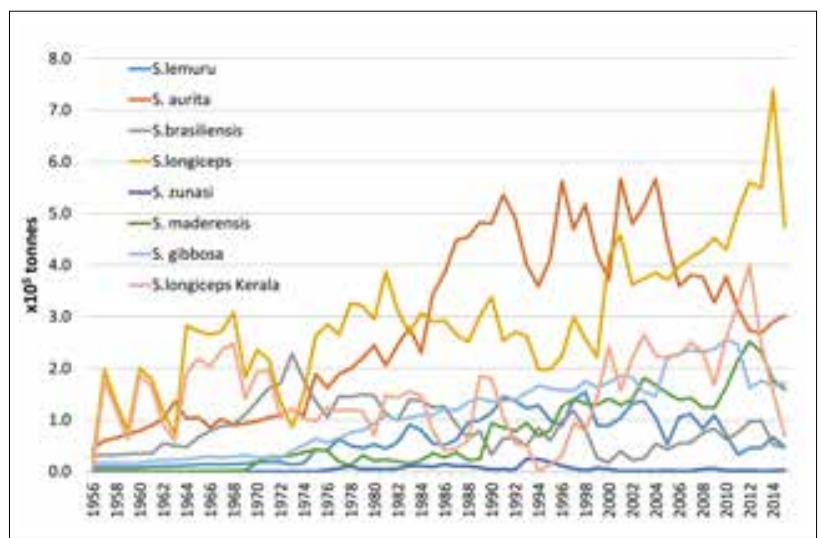

Fig. 13. Landings of major Sardinella species. Source: FAO 
Table 4. Decadal landings ( $\times 10^{5}$ tonnes) of major species of Sardinella and their contribution to total global landings of major Sardinella species

\begin{tabular}{|c|c|c|c|c|c|c|}
\hline Species / details & $1956-65$ & $1966-75$ & $1976-85$ & $1986-95$ & $1996-05$ & $2006-15$ \\
\hline Sardinella lemuru & 0.10 & 0.18 & 0.58 & 1.05 & 1.09 & 0.72 \\
\hline Sardinella aurita & 0.85 & 1.10 & 2.32 & 4.45 & 4.91 & 3.27 \\
\hline Sardinella brasiliensis & 0.42 & 1.38 & 1.30 & 0.72 & 0.52 & 0.70 \\
\hline Sardinella longiceps & 1.55 & 2.11 & 3.06 & 2.63 & 3.37 & 4.95 \\
\hline Sardinella zunasi & 0.00 & 0.00 & 0.07 & 0.12 & 0.03 & 0.02 \\
\hline Sardinella maderensis & 0.01 & 0.19 & 0.24 & 0.61 & 1.44 & 1.73 \\
\hline Sardinella gibbosa & 0.20 & 0.35 & 0.90 & 1.41 & 1.71 & 2.11 \\
\hline Total & 3.12 & 5.31 & 8.46 & 10.98 & 13.07 & 13.49 \\
\hline$\%$ of Sardinella to HAS & 3.0 & 3.6 & 5.8 & 4.9 & 6.2 & 7.3 \\
\hline
\end{tabular}

Percentage contribution of the species to total Sardinella landings

\begin{tabular}{|c|c|c|c|c|c|c|}
\hline Sardinella lemuru & 3.4 & 3.3 & 6.8 & 9.5 & 8.3 & 5.3 \\
\hline Sardinella aurita & 28.8 & 20.5 & 27.2 & 40.4 & 37.6 & 24.3 \\
\hline Sardinella brasiliensis & 14.3 & 26.1 & 15.5 & 6.6 & 4.0 & 5.2 \\
\hline Sardinella longiceps & 46.3 & 40.1 & 36.3 & 23.9 & 25.6 & 36.5 \\
\hline Sardinella zunasi & 0.0 & 0.0 & 0.8 & 1.1 & 0.3 & 0.2 \\
\hline Sardinella maderensis & 0.3 & 3.4 & 2.9 & 5.5 & 11.0 & 12.8 \\
\hline Sardinella gibbosa & 6.9 & 6.5 & 10.5 & 12.9 & 13.2 & 15.7 \\
\hline$\%$ contribution by oil sardine to world catch & 0.49 & 0.44 & 0.55 & 0.33 & 0.40 & 0.61 \\
\hline$\%$ contribution by oil sardine to HAS & 1.5 & 1.3 & 2.1 & 1.2 & 1.6 & 2.7 \\
\hline
\end{tabular}

India has been the major contributor in all the six decades (1956 to 2015) (Fig. 14, Table 5a, 5b). However, the percentage contribution of the species to the Sardinella group declined from $94.8 \%$ in $1966-75$ to $70.5 \%$ in $2006-15$. The fishery in Pakistan was just 6190 tonnes in 1956-65 which increased to 48,163 tonnes in $1986-95$ but declined in the following two decades. Similarly the landings in UAE increased from 2610 tonnes in 1956-65 to 8166 tonnes in 1986-95 and declined thereafter. Contrary to this, there was no sardine fishery in Oman during the first three decades, and increased

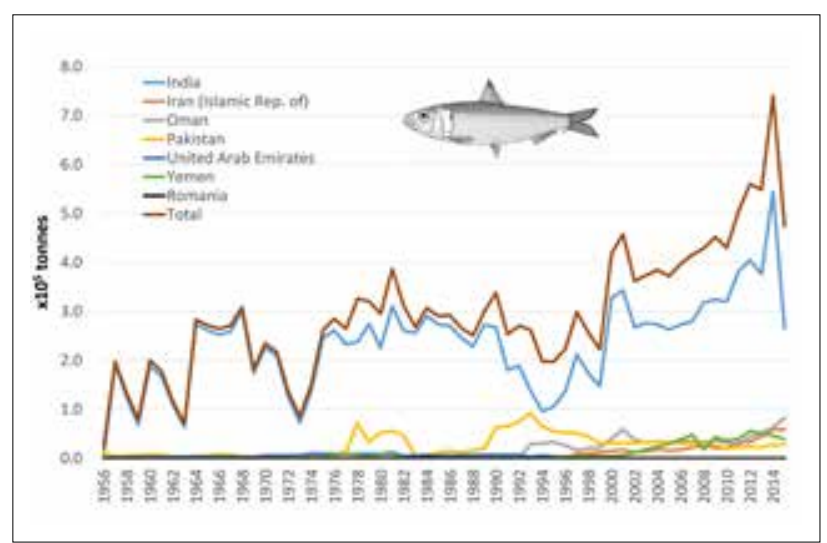

Fig.14. Indian oil sardine - country wise landings. Source: FAO from 9297 tonnes in 1986-95 to 44,372 tonnes in the last decade. The sardine fishery in Yemen, also increased during the last two decades.

The oil sardine fishery of Kerala (the major State contributing to all India catch) has declined and collapsed during the last century also and the reasons have been identified to be environmental especially those related to upwelling and rainfall (Raja, 1969; Longhurst and Wooster, 1990; Madhupratap et al., 1994; Jayaprakash, 2002; Krishnakumar et al., 2008; Xu and Boyce, 2009). Oil sardine landing of Kerala was highest in 2012 (399,786 tonnes) and thereafter started declining, reaching the lowest during the present century 2016 (45,958 tonnes). Recent studies have shown that this is related to a combination of factors including rainfall variation, overfishing and recruitment failure (Kripa et al., 2018). These observations give an indication that historic declines of oil sardine along Kerala coast may also be related to ocean atmospheric processes and there are chances that these may occur in future at more frequent intervals. Hence detailed integrated multidisciplinary studies on the finer details of larval recruitment and dynamics and eco-physiological changes subsequent to environmental changes has to be initiated. 
Table 5a. Decadal average annual landings ( $\times 10^{5}$ tonnes) of Sardinella longiceps in different countries

\begin{tabular}{lllllll}
\hline & $1956-66$ & $1966-75$ & $1976-85$ & $1986-95$ & $1996-05$ & $2006-15$ \\
\hline India & 1.46 & 2.00 & 2.62 & 1.99 & 2.42 & 3.49 \\
\hline Iran & 0.00 & 0.00 & 0.00 & 0.00 & 0.13 & 0.34 \\
\hline Oman & 0.00 & 0.00 & 0.00 & 0.09 & 0.32 & 0.44 \\
\hline Pakistan & 0.06 & 0.04 & 0.30 & 0.48 & 0.37 & 0.27 \\
\hline Yemited Arab Emirates & 0.03 & 0.06 & 0.08 & 0.06 & 0.02 & 0.00 \\
\hline Combined & 0.01 & 0.01 & 0.05 & 0.00 & 0.11 & 0.42 \\
\hline
\end{tabular}

Table 5b. Percentage contribution by each country to global oil sardine landing

\begin{tabular}{lllllll}
\hline & $1956-66$ & $1966-75$ & $1976-85$ & $1986-95$ & $1996-05$ & $2006-2015$ \\
\hline India & 93.9 & 94.8 & 85.8 & 75.9 & 71.8 & 70.5 \\
\hline Iran & 0.0 & 0.0 & 0.0 & 0.0 & 3.7 & 6.8 \\
\hline Pakistan & 0.0 & 0.0 & 0.0 & 3.5 & 9.5 & 8.9 \\
\hline United Arab Emirates & 4.0 & 1.9 & 9.9 & 18.3 & 11.0 & 5.4 \\
\hline Yemen & 1.7 & 2.8 & 2.7 & 2.3 & 0.5 & 0.0 \\
\hline
\end{tabular}

\section{Round sardine Sardinella aurita}

S. aurita commonly known as the Round sardine forms a fishery in 19 countries from Asia, Africa, America and Europe. The average landings of this species for the period 1956-2015 was almost equal to that of S. longiceps (Fig.15). The average decadal landing of this species increased from $0.85 \times 10^{5}$ tonnes in $1956-65$ to $4.91 \times 10^{5}$ tonnes in 1996-2005. The landing almost doubled during 1986-1995 (4.45 × $10^{5}$ tonnes) from that of 1976-1985 (2.32 × 105 tonnes) and during this period S. aurita was the major species of Sardinella, surpassing the landing of $S$. longiceps. However, during the last decade, the average annual landing declined. Among these the most important contributors are Senegal, Venezuela, Ghana, Russian Federation and the Netherlands.

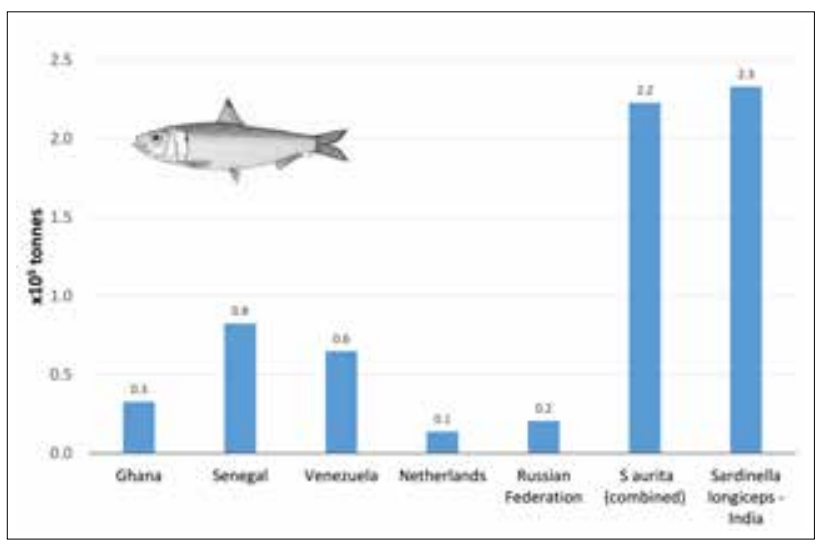

Fig.15. Comparison of S. aurita (Average 1956-2015) landings. Source: FAO
Increasing temperature, intense upwelling and high primary production has been found to increase the recruitment success of $S$. aurita along the Northwest African coast in the late 1990s and this has counterbalanced the impact of fisheries (Zeeberg et al., 2008). The fluctuations in the fishery of $S$. aurita off northeastern Venezuela, has been ascribed partly to the intensity of coastal upwelling (Rueda-Roa et al., 2017).

\section{Brazilian sardine Sardinella brasiliensis}

Commonly known as the Brazilian sardine, S. brasiliensis forms a commercial fishery only along Brazil. The average landings increased from $0.42 \times 10^{5}$ tonnes in 1956-65 to $1.38 \times 10^{5}$ tonnes during $1966-75$, becoming the second most important species of Sardinella. However, the landings decreased in the following years and in 1996-2005 the landings decreased to $0.52 \times 10^{5}$ tonnes. The landings are much less than the oil sardine landings from Indian subcontinent (Fig. 16).

The reasons for decline in fishery of $S$. aurita $(=S$. brasiliensis) during the 1970s has been attributed to several factors. Overfishing of spawning stock, unfavourable environmental conditions during spawning and recruitment failure due to inability of larvae to survive have been identified as reasons for stock declines (Matsuura,1996). The Brazilian Government had introduced fisheries management measure like ban on fishing during spawning period, control on fishing effort and setting of minimum size (Matsuura, 1996). Jablonski (2007) has indicated that reduction in spawning stock biomass is a major 
reason for stock decline and that reduction in fishing effort is a key step in stock revival.

\section{Gold stripe Sardinella Sardinella gibbosa}

Commonly known as Gold stripe Sardinella, is fished mostly from Indonesia. The decadal average of this species was only $0.20 \times 10^{5}$ tonnes, which steadily increased to $2.11 \times 10^{5}$ tonnes in 2005 -2016. Thus during the last three decades this species from Indonesia emerged as the third most dominant Sardinella. The average landings for the period 1995-2016 was $1.11 \times 10^{5}$ tonnes which is half that of oil sardine from India (Fig. 16).

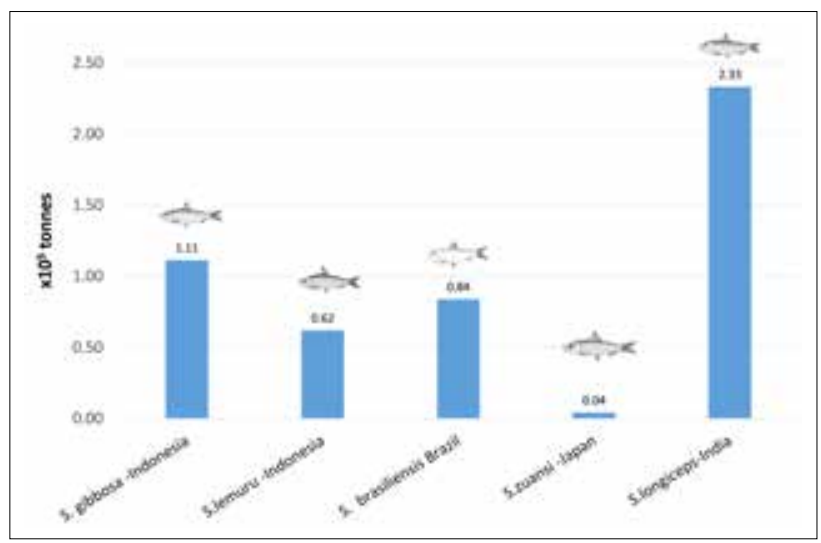

Fig.16. Comparison of S. gibbosa, S. lemuru, S. brasiliensis, S. zuansi and S. S. longiceps-India landings during 1956-2015. Source: FAO

\section{Bali sardine Sardinella lemuru}

Commonly known as the Bali Sardine, this is fished mostly from Indonesia (Fig. 16). The average annual landings of this species increased from $0.10 \times 10^{5}$ tonnes in $1956-65$ to $1.09 \times 10^{5}$ tonnes in 1996 -2005. In the last decade however, the fishery has declined. This species is also influenced by upwelling and observed around Java, especially the Bali Strait area that is very close to the coast (Polunin, 1983).

\section{Madeiran Sardinella Sardinella maderensis}

Commonly known as the Madeiran Sardinella, this species forms a fishery in Africa and Europe (Fig.17). This species which is fished in almost 10 countries has witnessed growth over the decades. From an average annual landing of $0.01 \times 10^{5}$ tonnes in 1995-2006, the landings increased to $1.73 \times 10^{5}$ tonnes in 2006-2015. The major countries are Senegal, Morocco and Ghana.

\section{Japanese Sardinella Sardienlla zuansi}

Japanese sardinella forms a minor fishery in Japan. The landings were very low, but increased from $0.08 \times 10^{5}$ tonnes in 1976-

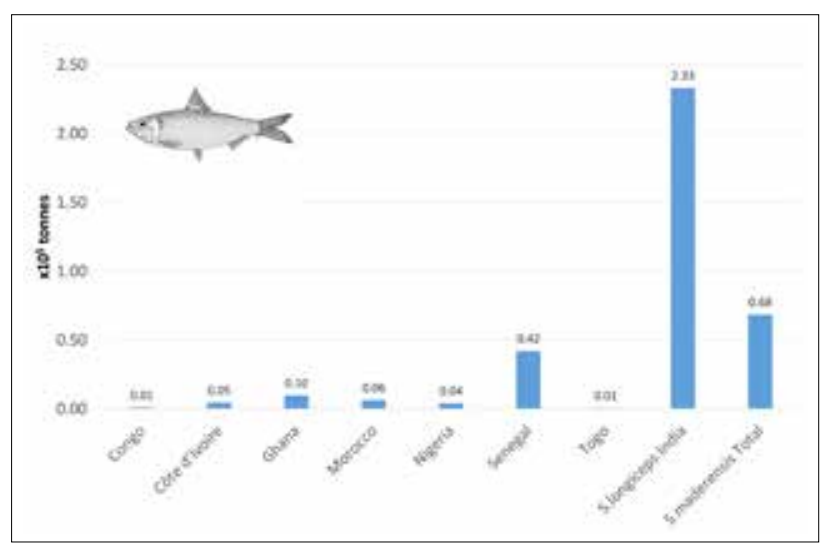

Fig. 17. Country-wise average annual landings of $S$. maderensis and $S$. longiceps-India during the period 1956-2015. Source FAO

1985 to $1.1 \times 10^{5}$ tonnes in $1986-1995$ but decreased thereafter (Fig. 16, Table 4).

\section{Contribution of oil sardine to Indian marine fish landings}

Though there are no direct statistics on the landings of sardine along the Kerala coast during the 19th century, estimates of landings were made based on the raw material used in the sardine oil and manure industry and also from the export figures of sardine oil from Cochin Port in central Kerala (Fig. 18, 19 and 20). During the period 1925 to 1950 , highest landing of 40,424 tonnes was during 1933-34 (Fig. 20). During this period only a small part of the catch was used for domestic consumption and the major share was procured by the fish oil plants. About 647 factories were functional along north Kerala coast during 1920's. The fishery was poor in 1941- 42 (Fig. 20)

The all India marine fish landings as per CMFRI database increased from $7.2 \times 10^{5}$ tonnes in 1956 to a highest of $39.4 \times 10^{5}$ tonnes in 2012 and the Indian oil sardine landings also increased

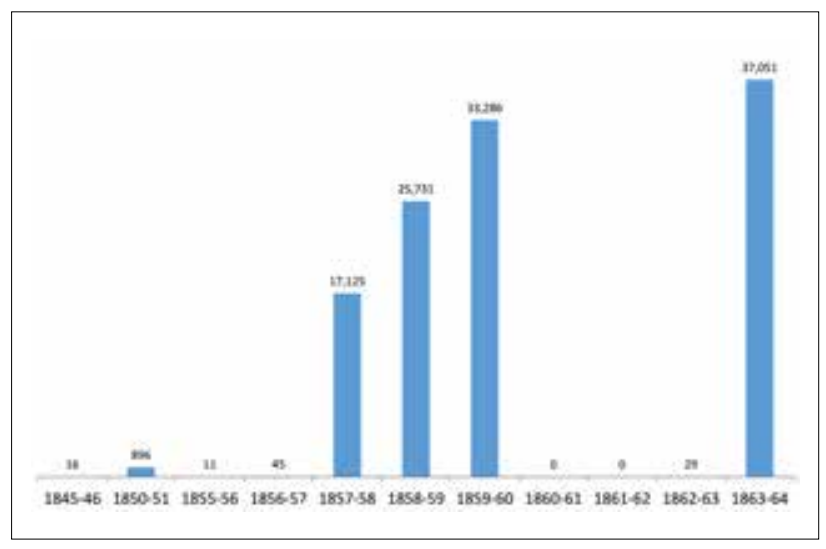

Fig. 18. Quantity of estimated oil sardine used for curing during 1845 to 1864 in Kerala 


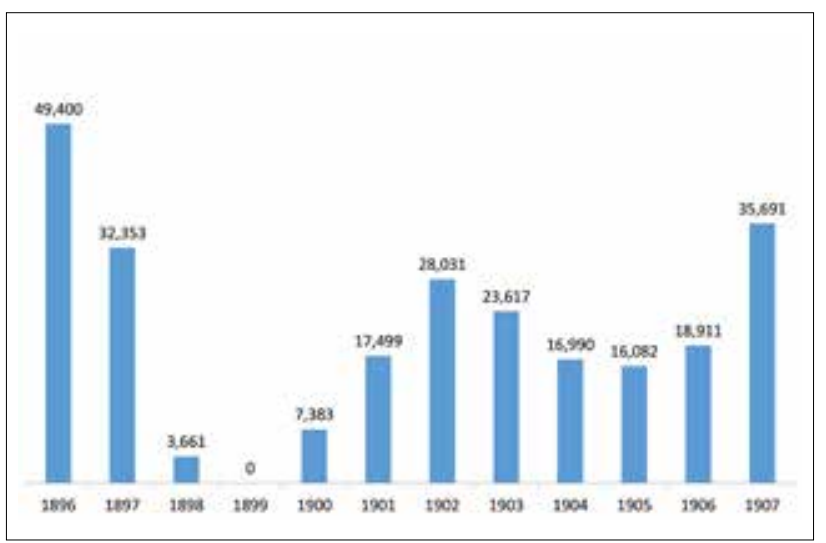

Fig. 19. Sardine catch (in tonnes) in Kerala during 1896 to 1907 (Ref: Hornell 1910; estimated based on quantity of fish cured)

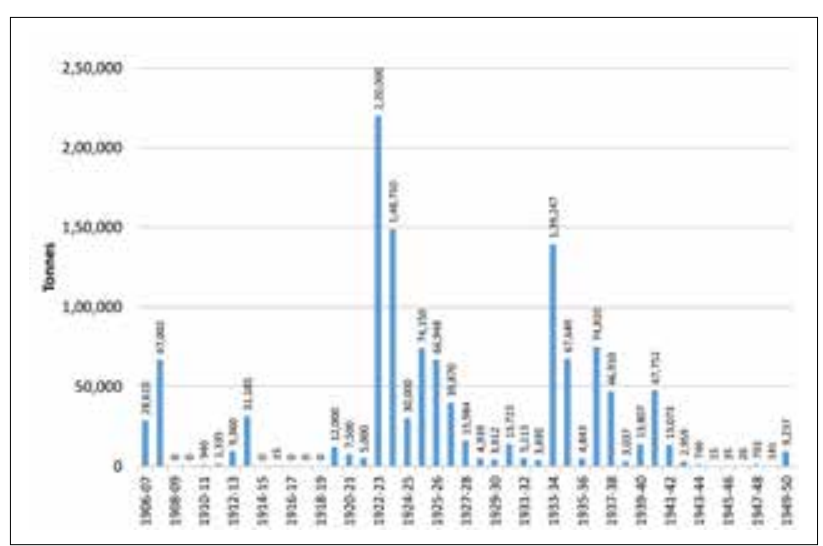

Fig. 20. Estimated Indian oil sardine catch in tonnes based on data from registers on sardine landings maintained in curing yards (Ref: Hornell 1937; Nair and Chidambaram, 1951)

from $0.1 \times 10^{5}$ to $7.2 \times 10^{5}$ tonnes during this period from various maritime states (Fig. 21). After 2012, the all India marine fish catch as well as the oil sardine catch declined (Fig. 22).

The oil sardine has been one of the major resources of Indian marine fisheries (Rohit et al., 2019). During the period 1964 to 1969, the oil sardine has been contributing between 25 to 35 percent of the Indian marine fish landing (Fig. 23). However, during the period from 1985 to 1999 , the contributions were lower than 10\%, the lowest was in 1956 when it was just 1\% and then in 1994, when it was only $2 \%$ of the all India marine fish landings.

\section{Management of sardine fishery-a global overview}

In the United States, management of Californian sardine has been a matter of concern since last century. Since 2000, the commercial sardine fishery off California, Oregon, and Washington has been managed by Pacific Fishery Management Council under the Coastal Pelagic Species Fishery Management

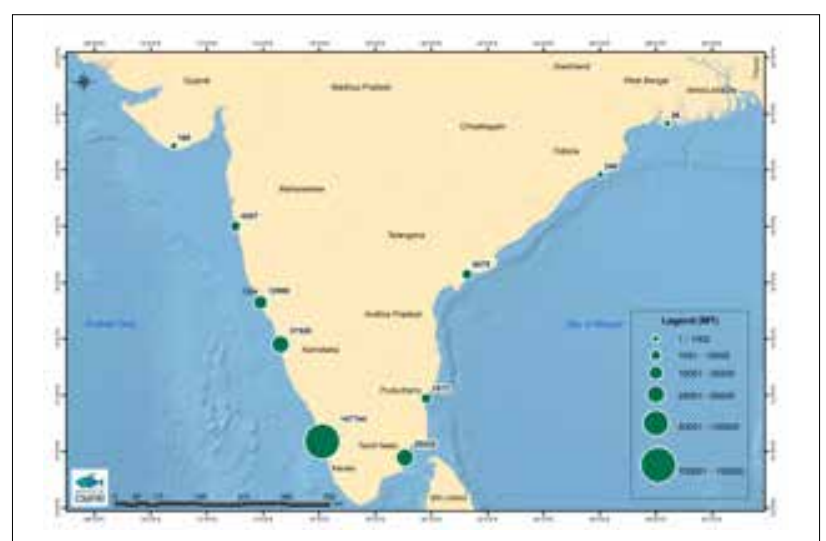

Fig. 21. GIS map showing state wise contribution to oil sardine production (long term average (1996-2015)

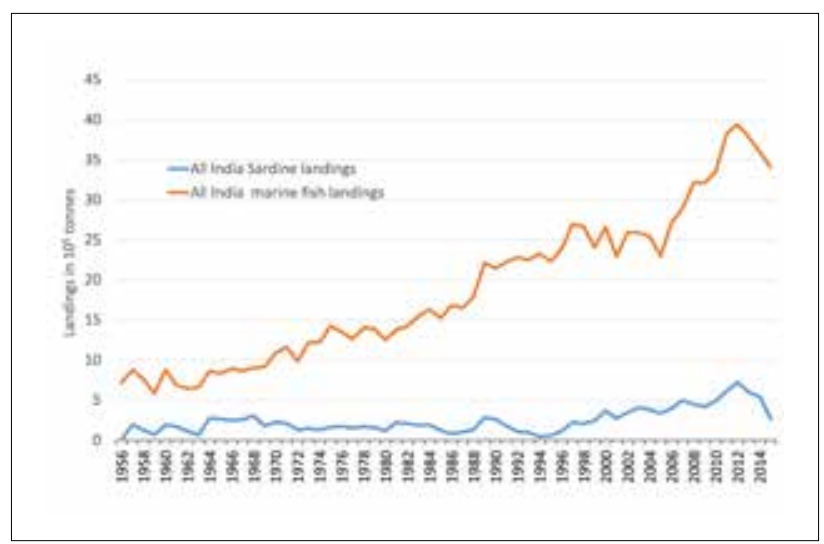

Fig. 22. Comparison of all India marine fish landings and Indian oil sardine landings. Source: CMFRI

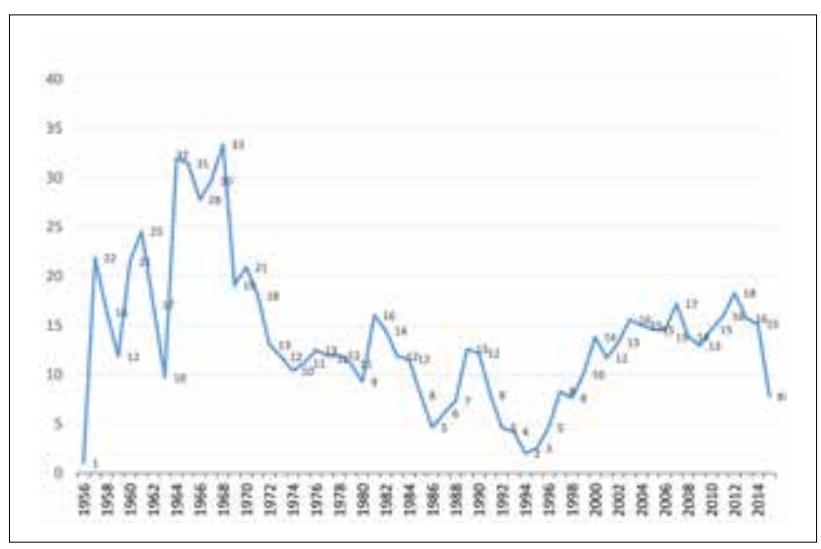

Fig. 23. Percentage contribution of oil sardine in all India marine fish landings. Source: CMFRI

Plan. Annual coast-wide harvest limits are derived from biomass estimates generated by an annual stock assessment (Hill et al., 2014). The stock assessment develops a population model that incorporates various data sources, such as age and other biological information. Multiple research surveys including the 
daily and total egg production (DEP, TEP) surveys are conducted. Apart from this, the Department of Fish and Game (DFG) pilots and biologists, along with partners, use new technological tools such as aerial surveys to study the sardine abundance (Kirk et al., 2014). The sardine fishery was severely affected during the last El Nino, and the quota open for fishing was very low during the previous three years and therefore, the fishery was closed in 2016. The US government under its Magnusson Stevens Fisheries Conservation and Management Act also provides financial assistance to fishers when a commercial fishery fails due to man-made and natural population declines (Upton, 2014)

Japan has one of the world's oldest and most successful marine fisheries co-management regimes (Matsuda et al., 2010). Based on the Fisheries Law of 1949 and the Fisheries Cooperative Associations Law of 1948, qualified individuals living in the coastal community were entitled as coastal fishers by rights and licenses. Fisheries cooperative associations (FCAs), the organization of local fishers, are the management body of local fisheries and resources (Matsuda et al., 2010). Based on both the traditional and scientific knowledge on the local environment, each FCA establishes detailed rules on the fisheries operations on the local fishing grounds, and the Government supports such activities by provisioning legal and scientific information and subsidies (Makino and Matsuda, 2005). In Japan, where wide natural stock fluctuations of sardine, anchovy and chub mackerel are well known, Matasuda and Katsukawa (2002) have suggested 'Adaptive management'. They opine that commercial fisheries should switch their target to the next dominant species before the stock of the present dominant species collapses. This type of management incorporates uncertainties in stock assessment, ecosystem processes and human impacts into management procedures.

South Africa has a large purse seine fishery that harvests predominately sardine $S$. sagax and the anchovy Engraulis encrasicolus. The fluctuations in the fishery of sardine led to the management of the pelagic fishery through an operational management procedure that aims to maximise overall catches of sardine and anchovy and minimising risk of resource collapse (GLOBEC, 2013). This is identified as Ecosystem Approach to Management of Resources (EAMR) with a range of indicators and other management tools. Separate total allowable catches are set for anchovy and sardine, in addition to a total allowable bycatch set for juvenile sardine taken in anchovy-directed fishing.

In Philippines, the sardine (S. lemuru) contribute significantly to the nutritional security of the coastal community, besides being an employment provider (Rola et al., 2018). When the sardine catch declined by $50 \%$ in 2011 , to protect the resource and livelihood of coastal communities, a 'no fishing zone' conservation area of 13,987 square kilometres in Zamboanga
Peninsula (ZamPen), was identified and a closed fishing season for commercial-scale harvest of sardines was enforced for three months every year for a period of three years.

Categorizing this policy as a success, Rola et al. (2018) attribute the success to three major factors 1 ) the strong link between the sardine industry and the science community, e.g., academicians/ research institutions who supported by identifying the right implementation period 2) stakeholders' participation in the policy process and 3) provision of training for employees who will be out of jobs during the closed season.

The "ZamPen" success story, has prompted the Bureau of Fisheries and Aquatic Resources (BFAR) and Oceana Philippines to create a National Sardine Management Plan (Sagip Sardines) first of its kind for the country for this resource which would ensure science-based fisheries management and protect against the risk losing this valuable source (Manila Bulletin, 2017).

\section{Global-Precautionary management approach for sardines}

Globally forage fishes have more importance as prey of other larger fishes. Economic importance of forage fish has been estimated as US $\$ 16.5$ billion of which US\$ 5.6 billion is the direct value and US $\$ 11.3$ billion is the supportive value of forage fish to other commercial catch (Pikitch, et al., 2012). Cascading effect of decline in forage fishes in the ecosystem has been a major concern world over. A targeted study was conducted by the Lenfest Forage Fish Task Force which consisted of 13 eminent scientists from around the world to provide practical advice on the sustainable management of forage fish. In April 2012 a report titled, "Little fish, big impact" provided new approaches to management of forage fish (Pikitch, et al., 2012). They found that conventional management can be risky for forage fish because it does not adequately account for their wide population swings and high catchability. It also fails to capture the critical role of forage fish as food for marine mammals, seabirds, and other higher trophic level fishes. The report recommends the 'precautionary management approach' such as cutting catch rates in half in many ecosystems and doubling the minimum biomass of forage fish that must be left in the water, compared to conventional management targets (Pikitch, et al., 2012).

\section{Management of oil sardine fisheries-India}

Since sardines have formed a major resource of local importance in Kerala, southwest coast of India, most management measures related to this resource pertain to this maritime state. In 1943, when the sardine fishery declined and collapsed, the then Presidency of Madras, which had the control of fisheries of Kerala State banned fishing of oil sardine in Malabar which was later 
extended to another two years from 1945. This rule prohibited use of small meshed nets for immature sardine all throughout the year and also controlled juvenile fishing by prohibiting landing of oil sardine below $15 \mathrm{~cm}$. The legislation lapsed in 1947 due to practical difficulties encountered in enforcement.

In 2014, when the sardine fishery reached the declined status, Mohamed et al. (2014) recommended to the Government to ban fishing and landing of oil sardines below $10 \mathrm{~cm}$. In the same year Government of Kerala promulgated the ban on fishing of juvenile oil sardines. The fishermen also understood the need for protecting juveniles and abstained from juvenile fishery. Besides, the fact that oil sardine off Kerala were consistently fished over their prescribed MSY for 4 years (Kripa et al., 2018) shows that the fishery did not have any harvest strategy and control rules. This is necessary for sustainable harvests.

\section{Conclusions}

The comparison of variation in fishery of 12 species of commercially important sardines across the globe during the period 1956 to 2016 has clearly brought out the importance of oil sardine fishery along the Indian sub-continent which can be ranked as the second dominant sardine fishery in the world. Perusal of literature has identified the need to carry out detailed interdisciplinary collaborative eco-biological investigations especially on aspects like larval retention period, larval drift, optimal window concepts, interspecies competitions and climatological investigations with special reference to warmcold phase controlling the population of Indian oil sardine in the coastal upwelling zone of southeastern Arabian Sea. The temperate water HAS resources have been extensively studied through programs such as the California Cooperative Oceanic Fisheries Investigations (CalCOFI) which was a unique partnership of the California Department of Fish \& Wildlife, NOAA Fisheries Service and Scripps Institution of Oceanography formed in 1949 to study the ecological aspects of the sardine population collapse off California. Similarly the Small Pelagics and Climate Change (SPACC) project of GLOBEC in 2008 also investigated the reasons for fluctuations. The need to study the role of variations in the upwelling zones of other Asian countries in controlling the recruitment success and investigate the synchronisation if any on the small pelagic of these regions is also required to strengthen the preparedness of small scale fishers who largely depend on these coastal resources. It is suggested that a program on long term ecological research is initiated in the coastal upwelling zones of southeast Asian region.

\section{References}

Bakun, A. and P. Cury. 1999. The "school trap": A mechanism promoting largeamplitude out-of-phase population oscillations of small pelagic fish species. Ecol. Lett., 2: 349-351.
Banse, K. 1959. On upwelling and bottom-trawling off the southwest coast of India. J. Mar. Biol. Assoc. India, 1: 33-49.

Brosset, P., J. M. Fromentin, E. V. Beveren, J. Lloret and V. Marques. 2017. Spatiotemporal patterns and environmental controls of small pelagic fish body condition from contrasted Mediterranean areas. Prog. Oceanogr., 151: 149-162.

Cury, P. and C. Roy. 1989. Optimal environmental window and pelagic fish recruitment success in upwelling areas. Can. J. Fish. Aquat. Sci., 46: 670-680.

FA0. 2016. Food and Agriculture Organization. Fishery and aquaculture statistics yearbook 2014. Rome, Italy. 105 pp.

Galindo-Cortes, G., J. A. Anda-Montanez, F. Arreguín-Sánchez, S. Salas and E. F. Balart. 2010. How do environmental factors affect the stock-recruitment relationship? The case of the Pacific sardine (Sardinops sagax) of the northeastern Pacific Ocean. Fish. Res., 102: 173-183.

GLOBEC. 2013. EUR-OCEANS Knowledge Transfer Unit, Plymouth Marine Laboratory, UK. http://www.vliz.be/wiki/Ecosystem_Approach_to_the_South_African_small_ pelagic fisheryAccessed on 01.12.201 $\overline{7}$.

Hill, K. T., P. R. Crone, N. C. H. Lo, D. A. Demer, J. P. Zwolinski, E. Dorval and B. J. Macewicz. 2014. Assessment of the Pacific sardine resource in 2014 for U.S. management in 201415. Pacific Fishery Management Council, April 2014 Briefing Book.

Hornell, J. 1937. The fishing methods of Madras Presidency. Part II. Malabar Coast. Madras Fish. Bull., 27 (1): 1-69.

Izquierdo-Peña, V., S. E. Lluch-Cota, M. E. Hernandez-Rivas and R. O. Martínez-Rincón. 2019. Revisiting the Regime Problem hypothesis: 25 years later. Deep-Sea Res., Part II. 159: 4-10.

Jablonski, S. 2007. The Brazilian sardine. Is there any room for modelling? Pan-Am. J. Aquat. Sci., 2(2): 86-93

Jayaprakash, A. A. 2002. Long term trends in rainfall, sea level and solar periodicity: A case study for forecast of Malabar sole and oil sardine fishery. J. Mar. Biol. Assoc. India, 44: 163-175.

Kawasaki, T. 1983. Why do some pelagic fishes have wide fluctuations in their numbers?-Biological basis of fluctuation from the viewpoint of evolutionary ecology. FAO Fish. Rep., 291: 1065-1080.

Kirk, L., D. Porzio and A. Kesaris. 2014. Aerial sardine surveys in the Southern California Bight. California Fish and Game, 100(2): 260-275.

Kripa, V., K. S. Mohamed, K. P. Said Koya, R. Jeyabaskaran, D. Prema, S. Padua, S. Kuriakose, P. S. Anilkumar, P.G. Nair, T. V. Ambrose, G. Dhanya, K. S. Abhilash, J. Bose, N. D. Divya, A. S. Shara and P. G. Vishnu. 2018. Overfishing and Climate Drives Changes in Biology and Recruitment of the Indian Oil Sardine Sardinella longiceps in Southeastern Arabian Sea. Front. Mar. Sci., 5 (443): 1-20.

Krishnakumar, P. K., K. S. Mohamed, P. K. Asokan, T. V. Sathianandan, P. U. Zacharia, K. P. Abdurahiman, S. Veena and N. R. Durgekar. 2008. How environmental parameters influenced fluctuations in oil sardine and mackerel fishery during 1926-2005 along the southwest coast of India. Mar. Fish. Infor. Serv. T\& E Ser., 198: 1-5.

Lindegren, M., D. M. Checkley, Jr., T. Rouyer, A. D. Mac Call and N. C. Stenseth. 2013. Climate, fishing, and fluctuations of sardine and anchovy in the California Current. Proc. Natl. Acad. Sci. USA, 110 (33): 13672-13677.

Lluch-Belda, D, R. J. M. Crawford, T. Kawasaki, A. D. MacCall, R. H. Parrish, R. A Schwartzlose and P. E. Smith. 1989. World wide fluctuations of sardine and anchovy stocks: the regime problem. S. Afr. J. Mar. Sci., 8:195-205.

Lluch-Belda, D., S. Hernandez-Vazquez, D. B. Lluch-Cota, C. A. Salinas-Zavala and R. A. Schwartzlose. 1992. The recovery of the Californian sardine as related to global change. California Department of Fish \& Wildlife. CalCOFI Report, 33: 50-59.

Longhurst, A. R. and W. S. Wooster. 1990. Abundance of oil sardine (Sardinella longiceps) and upwelling on the southwest coast of India. Can. J. Fish. Aquat. Sci., 47: 2407-2419.

Madhupratap, M., S. R. Shetye, K. V. Nair and N. R. Sreekumaran. 1994. Oil sardine and Indian mackerel: Their fishery problems and coastal oceanography. Curr. Sci., 66: 340-48.

Makino, M. and H. Matsuda. 2005. Co-management in Japanese coastal fisheries: Institutional features and transaction costs. Mar. Policy, 29: 441-450.

Manila Bulletin. 2017. BFAR, Oceana PH team up for National Sardine Framework Management Plan. https://newsbits.mb.com.ph/2017/03/29/bfar-oceana-phteam-up-for-national-sardine-framework-management-plan/ published on March 29th 2017; Accessed on -01.12.2017

Mata, C., N. M. Martinez and M. Hammann. 1995. The rise and fall of the Pacific sardine, Sardlnops sagax Caeruleus Girard, in the Gulf of California, Mexico. CalCOFI Rep., 36: 136-143.

Matsuda, H. and T. Katsukawa. 2002. Fisheries management based on ecosystem dynamics and feedback control. Fish Oceanogr., 11(6): 366-370.

Matsuda, H., M. Makino, M. Tomiyama, S. Gelcich and J. C. Castilla. 2010. Fishery management in Japan. Ecol. Res., 25: 899-907.

Matsuura, Y. 1996. A probable cause of recruitment failure of the Brazilian sardine Sardinella aurita population during the 1974/75 spawning season. South Afr. J. Mar. Sci., 17: 29-35.

Mohamed K. S. and S. Veena. 2016. How long does it take for tropical marine fish stocks to recover after declines? Case studies from the southwest coast of India. Curr. Sci., 110(4): 584-594. 
Mohamed, K. S., P. U. Zacharia, G. Maheswarudu, T. V. Sathianandan, E. M. Abdussamad, U. Ganga, S. L. Pillai, K. S. Sobhana, R. J. Nair, J. Josileen, R. D. Chakraborty, S. J. Kizhakudan and T. M. Najmudeen. 2014. Minimum Legal Size (MLS) of capture to avoid growth overfishing of commercially exploited fish and shellfish species of Kerala. Mar. Fish. Infor. Serv. T\& E Ser., 220: 3-7.

Mullon, C., P. Freon and P. Cury. 2005. The dynamics of collapse in world fisheries. Fish. Fish., 6: 111-120.

Nair, E. V. and K. Chidambaram, 1951. A review of the Indian Oil sardine fishery. Proc. Nat. Inst. Sci. India, 17(1): 71-85.

Peck, M. A., P. Reglero, M. Takahashi and I. A. Catalan. 2013. Life cycle ecophysiology of small pelagic fish and climate-driven changes in populations. Prog. Oceanogr., 116: 220-245.

Petitgas, P., D. H. Secor, I. Mc-Quinn, G. Huse and N. Lo. 2010. Stock collapses and their recovery: mechanisms that establish and maintain lifecycle closure in space and time. ICES J. Mar. Sci., 67: 1841-1848.

Pikitch, E., P. D. Boersma, I. L. Boyd, D. O. Conover, P. Cury, T. Essington, S. S. Heppell, E. D. Houde, M. Mangel, D. Pauly, E. Plagányi, K. Sainsbury and R. S. Steneck. 2012. Little Fish, Big Impact: Managing a Crucial Link in Ocean Food Webs. Lenfest Ocean Program. Washington, DC. 108 pp.

Pikitch, E. K., J. R. Konstantine, T. Essington, S. Christine, D. Pauly, R. Watson, U. R. Sumaila, P. D. Boersma, I. L. Boyd, D. O. Conover, P. Cury, S. S. Heppell, E. D. Houde, M. Mangel, E. Plagányi, K. Sainsbury, R. S. Steneck, T. M. Geers, N. Gownaris and S. B. Munch. 2014. The global contribution of forage fish to marine fisheries and ecosystems. Fish Fish., 15: 43-64.

Pillai, N. G. K., U. Ganga and A. A. Jayaprakash. 2003. Indian Oil Sardine. In: M. Mohan Joseph and A. A. Jayaprakash (Eds.) Status of Exploited Marine Fishery Resources of India. Cochin, p. 18-24.

Polunin, N. C. 1983. The marine resources of Indonesia. Oceanogr. Mar. Biol. Ann. Rev., 21: 455-531.

Raja, A. B. T. 1969. The Indian Oil Sardine. Bulletin of Central Marine Fisheries Research Institute, Kochi, India 16: 1-128.

Rohit, P., M. Sivadas, E. M. Abdussamad, A. M. R. Margaret, K. P. Koya, U. Ganga, S. Ghosh, K. M. Rajesh, K. M. Koya, C. Anulekshmi, K. G. Mini, G. George, S. K. Roul, S. Surya, S. Sandhya, E. Vivekanandan, T. B. Retheesh, D. Prakasan, M.S. Kumar, S. Mohan, R. Vasu and V. Supraba. 2018. The Enigmatic Indian Oil Sardine: An Insight. CMFRI Spl. Publ., 130: 1-156.

Rola, A. C., T. A. Narvaez, M. A. Naguit, D. Elazegui, B. B. Brillo, M. Paunlagui, H. C. Jalotjot and C. Cervantes. 2018. Impact of the closed fishing season policy for sardines in Zamboanga Peninsula, Philippines. Mar. Policy, 87: 40-50.
Rueda-Roa D, J. Mendoza, F. Muller-Karger, J. J. Cardenas, A. Achury and Y. Astor. 2017. Spatial variability of Spanish sardine (Sardinella aurita) abundance as related to the upwelling cycle off the southeastern Caribbean Sea. PLOS ONE, 12(6).

Salim, S. S., K. S. Mohamed, P. K. Safeena and R. Remya. 2017. Effect of declining oil sardine landings on the livelihoods of traditional fishers in Kerala. J. Indian Fish. Assoc., 44 (2): 63-70.

Schwartzlose, R. A., J. Alheit, A. Bakun, T. R. Baumgartner, R. Cloete, R. J. M. Crawford, W. J. Fletcher, Y. Green-Ruiz, E. Hagen, T. Kawasaki, D. Lluch-Belda, S. E. LluchCota, A. D. MacCall, Y. Matsuura, M. O. Nevarez-Martinez, R. H. Parrish, R. Claude, R. Serra, K. V. Shust, M. N. Ward and J. Z. Zuzunaga. 1999. Worldwide large-scale fluctuations of sardine and anchovy populations. S. Afr. J. Mar. Sci., 21: 289-347.

Sonu, S. C. 2001. Sardine Fisheries Trade and Market of Japan. NOAA-TM-NMFSSWR-038 US Department of Commerce.; 51 p. Available at http://swfsc.noaa.gov/ publications/TM/SWR/NOAA-TM-NMFS-SWR-038.

Suda, M., T. Akamine and T. Kishida. 2005. Influence of environment factors, interspecific-relationships and fishing mortality on the stock fluctuation of the lapanese sardine, Sardinops melanostictus, off the Pacific coast of Japan. Fish. Res., 76: 368-378

Sumaila, U. R., W. W. L. Cheung, V. W. Y. Lam, D. Pauly and S. Herrick. 2011. Climate change impacts on the biophysics and economics of world fisheries. Nature Clim. Change, 1: 449-456.

Upton, H. F. 2014. Commercial Fishery Disaster Assistance. Congressional Research Service 7: 5700. www.crs.gov/RL34209.

Vasilakopoulos, P., G. O. Finbarr and C. T. Marshall. 2011. Misspent youth: does catching immature fish affect fisheries sustainability? ICES J. Mar. Sci., 68(7): 1525-1534.

Worm, B., R, Hilborn, J. K. Baum, T. A. Branch, J. S. Collie, C. Costello, M. J. Fogarty, E. A. Fulton, J. A. Hutchings, S. Jennings, O. P. Jensen, H. K. Lotze, P. M. Mace, T. R. McClanahan, C. Minto, S. R. Palumbi, A. M. Parma, D. Ricard, A. A. Rosenberg, R. Watson and D. Zeller. 2009. Rebuilding global fisheries. Science, 325: $578-585$

Xu, C. and M. S. Boyce. 2009. Oil sardine (Sardinella longiceps) off the Malabar Coast: density dependence and environmental effects. Fish. Oceanogr., 18(5): 359-370.

Zeeberg, J., A. Corten, P. Tjoe-Awie, J. Coca and B. Hamady. 2008. Climate modulates the effects of Sardinella aurita fisheries off Northwest Africa. Fish. Res., 89: 65-75.

Zwolinski, J. P. and D. A. Demer. 2012. A cold oceanographic regime with high exploitation rates in the Northeast Pacific forecasts a collapse of the sardine stock. Proc. Nat. Acad. Sci., 11: 4175-4180. 